\title{
SECOVLJE SALINA NATURE PARK, SLOVENIA - NEW BUSINESS MODEL FOR PRESERVATION OF WETLANDS AT RISK
}

\section{A. SOVINC}

Received: $15 / 12 / 08$

Accepted: 30/12/08

\author{
Head, Secovlje Salina Nature Park, Slovenia \\ Secovlje Salina Nature Park \\ Soline d.o.o., Seca 115, SI-6320 Portoroz, Slovenia
}

*to whom all correspondence should be addressed: e-mail: andrej.sovinc@soline.si

\section{ABSTRACT}

Ecological management plan and its implementation for particular wetland are highly dependent on securing effective management tools, including management according to the management plan. The implementation of such a plan requires adequate resources, both in terms of human and financial support. The article demonstrates an innovative approach of business company, supporting sound ecological management and restoration of salt making process in the salt-works and Nature Park in Secovlje Salina (Slovenia).

The Secovlje Salina (6,5 km2), part of the Piran Salinas which comprises adjacent still active Strunjan Salina and already abandoned Lucija Salina, is situated on the Adriatic coast, at the mouth of the Dragonja River, in the southernmost stretch of the coastline of the Piran Bay. The area has been designated a Nature Park by the Government of Slovenia in 2001.

Due to difficult economic situation on the European market of salt, the production of salt in Secovlje Salina almost ceased. In the year 2003 the salt making company (Soline d.o.o.) has been bought by the telecommunication company Mobitel d.d. in order to safeguard natural and cultural heritage and landscape and to maintain the traditional salt making process. This new model of business relationship proved to be successful for both sides: initial investments in the reconstruction of salt making and park infrastructure resulted in direct economic benefits for the business company and for preservation of natural and cultural heritage and tradition. Public image of telecommunication company has raised: potential customers appreciate investments of business into protection of nature and culture which resulted in new subscriptions to the above telecommunication company.

KEYWORDS: saltworks, ecological management, business model, Secovlje Salina

\section{DESCRIPTION OF THE AREA}

The Secovlje Salina, part of the Piran Salinas which comprises adjacent still active Strunjan Salina and already abandoned Lucija Salina, is situated on the Adriatic coast, at the mouth of the Dragonja River, in the southernmost stretch of the coastline of the Piran Bay. The Secovlje Salina, extended over $6,5 \mathrm{~km} 2$, is among the most important natural and cultural heritage sites in Slovenia, and therefore designated as the Nature Park, Ramsar Site, Natura 2000 site and a cultural monument of national importance.

The Decree on the designation of the Nature Park states that »maintenence of traditional salt production is essential to conserve the rich and special biodiversity of the area «Salt, produced in Secovlje salt pans, is grown and harvested on the same principles and methods as it was done already centuries ago. Flora and fauna species were able to adapt to the presence of men during the last decades and this is an equilibrium of humans and nature, rarely seen in the modern world. Secovlje salt pans are the northernost salinas in the Adriatic Sea and one of the few in the Mediterranean where salt is still produced in the traditional way. 

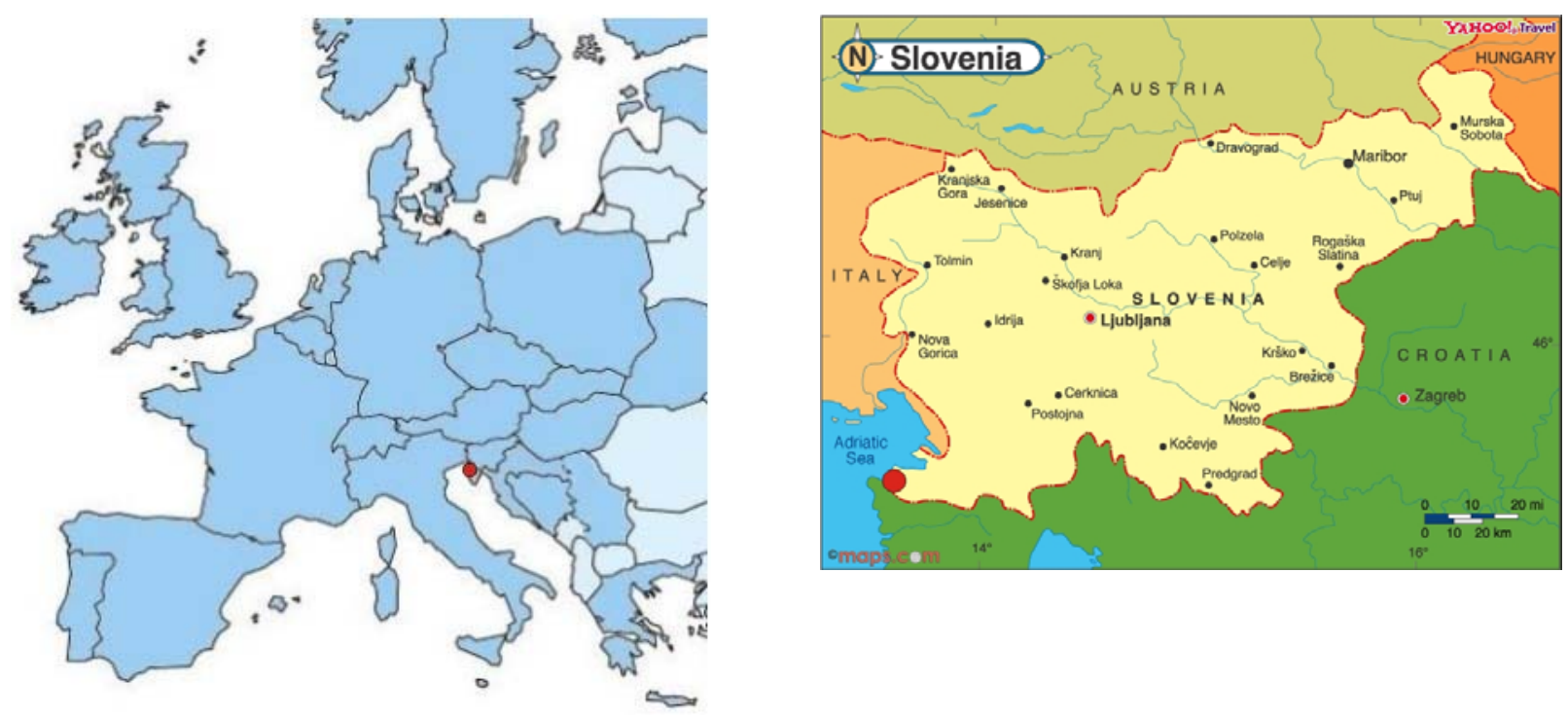

Figure 1. Map and position of Secovlje Salina

Traditional coastal salt production is one of the rare economic activities with a minor impact on the natural environment, with favourable influence on the conservation of the biodiversity and lanscape. The daily manual collecting of the salt, produced from the marine saturated brine with the help of the solar energy in the pans that have the bottom covered with a layer of the biosediment - 'petola', is a method centuries old. This way of collecting salt is still used in the salinas of Secovlje and Strunjan (together known as Piranske soline), that were just slightly renewed in the year 1904, when the Istra Region was administered by the AustroHungarian monarchy.

Manual work prevails in the saltpans. Traditional production of salt is, considering the work, intensive and markedly seasonal: with higher production costs and costly maintenance of the infrastructure, it is, if compared with other methods of salt production, uncompetitive. On the other hand, salt from Secovlje Salina is rich in minerals, purely white and therefore offers an opportunity to be advertised as naturally produced salt.

More than 270 birds have already been recored in the area. In addition, there are around 50 plant species, listed on the national Red Data Book as endangered species. Several species of plants, fish and invertebrates are specially adapted to hypersaline environment and are not found elsewhere in Slovenia (Rubinic, 2000).

\section{HISTORICAL DEVELOPMENT OF THE AREA UP TO THE RECENT TIMES}

The first written documents, describing the work in the Secovlje Salina, comes from the end of 13th Century. There are, however, other documents which indicate that the salt making activity in the region might be much older, dating back to the beginning of the 9th Century (Žagar, 1992).

The best period for the Secovlje Salina was from the 14 Century on. Parallel to the sinvasion « of cheaper North African salt to the European market, the production of salt in Secovlje Salina has ceased. Finally, on the southern part of the salina, the salt production process was stopped in the mid 1960s. Without regular maintenance, the dykes and sea-defense walls have collapsed and the salt making process was almost stopped in the entire salt pans area. This was the situation in the salina before the year 2001.

\section{DESCRIPTION OF THE NEW MANAGEMENT APPROACH}

Soon after the designation of the Secovlje Salina for the Nature Park (2001), the Republic of Slovenia has given the rights and obligations for management of the park and thus saltproduction to the private company. The Secovlje Salina Nature Park is therefore the first state-designated protected area in Slovenia where the concession for its management has been given to a business company (Soline d.o.o.), which is owned by the national biggest mobile phone company (Mobitel d.d.). 
The company Soline d.o.o. has a specific status in terms of management of the state protected area - Secovlje Salina Nature Park. The company has been given a concession, issued by the Government of the Republic of Slovenia, by which the company is responsible for the management of the state designated Nature Park and use of its natural resources. The company also has a specific duty in provision of public services in terms of protection of nature in the state owned property of the Secovlje Salina Nature Park. In return, the Republic of Slovenia provides funding for the management of the protected area which is reflected in a yearly program and financial plan of the Secovlje Salina Nature Park, however the rate of this contribution comprises only approximately $8 \%$ of the overall budget of the Park. The rest of the budget is generated by the Park itself, with the contribution of Mobitel d.d. In addition, the concession contract says that all the assets and investments in the Nature Park's infrastructure remain the property of the Republic of Slovenia, even after the time when the concession contract will expire (in the year 2023).

The main objectives for the management are: conservation of the wetland's ecological character, thus biodiversity and its economic and cultural values (cultural heritage).

These objectives will be achieved by:

- Maintaining the saline ecosystem and its diverse habitats that are sustaining the characteristic flora and fauna;

- Safeguarding the traditional production process and technology of salt making;

- Salt making which as an economic activity created the salina and was the main development objective in the history.

Management of the area is carried out in accordance with the specifications included in the decree on the establishment of the Nature Park and other legal background legislation and is put into practice through the management plan, approved by the Government of Slovenia.

\section{CHARACTERISTICS OF THE CONSESSION CONTRACT FOR MANAGEMENT}

The business relationship, where a company is given responsibility to manage a statedesignated protected area, is based on the presumption that the management of the area is carried out in accordance with the specifications included in the Decree on the establishment of the Nature Park and other legal background legislation and is put into practice through the management plan, approved by the Government of Slovenia. This management model presents an innovative form of protected area and salt making management. It is founded on the presumptions that the land in the park remains state property and that management of the area should strictly follow legal provisions (and is thus not given solely to the hands of the business company).

In return for the efforts and investments into protection and management of the heritage of the area, the private sector management body (Mobitel d.d., who owns the salt making company Soline d.o.o.) has been granted the possibility to exploit part of the income generated from salt making, tourism and other activities carried out in the area.

Mobitel d.d. has decided to invest in Secovlje Salina Nature park because of direct benefits, such as income from sale of salt and salt related products, part of the income form the visitor's revenues and also due to potential investments into the tourism infrastructure in the surrounding area which has benefited a lot by the restored image and attractions of almost deserted Salinas. But perhaps even more important for business company are indirect benefits: it was demonstrated that Mobitel d.d. company has secured a much better corporate reputation among mobile - phone customers in Slovenia due to the investments into protection of natural and cultural heritage and restoration of traditional salt making process in the Secovlje Salina. In addition, the company has been given an exclusive right to use the Park (its images) as means of promotion. Motives from Secovlje Salina have been successfully used in the Mobitel d.d. promotion campaign. But... one has to note that the intention of business company to protect and restore part of the national most important heritage and tradition was probably the most important consideration when Mobitel d.d. decided to invest in the "revival" of Secovlje Salina. 


\section{HOW TO MAKE THIS BUSINESS MODEL WORK?}

Mobitel d.d. has provided for initial cost of the restoration of the salt making process,'park management and infrastructure. In addition it helped in development of three trade mark programmes (related to salt/food, cosmetics and park products). Apart from the already existing Museum of salt making, additional attractions and infrastructure for visitors were created. These include multimedia centre for visitors, salt pans for demonstration of the process to the visitors, a shop and art gallery and several kilometres of walking and cycling paths. All these resulted in more than doubled number of visitors in three years who are obliged to pay an entrance fee and have a possibility to explore salina accompanied by park guides and expert.

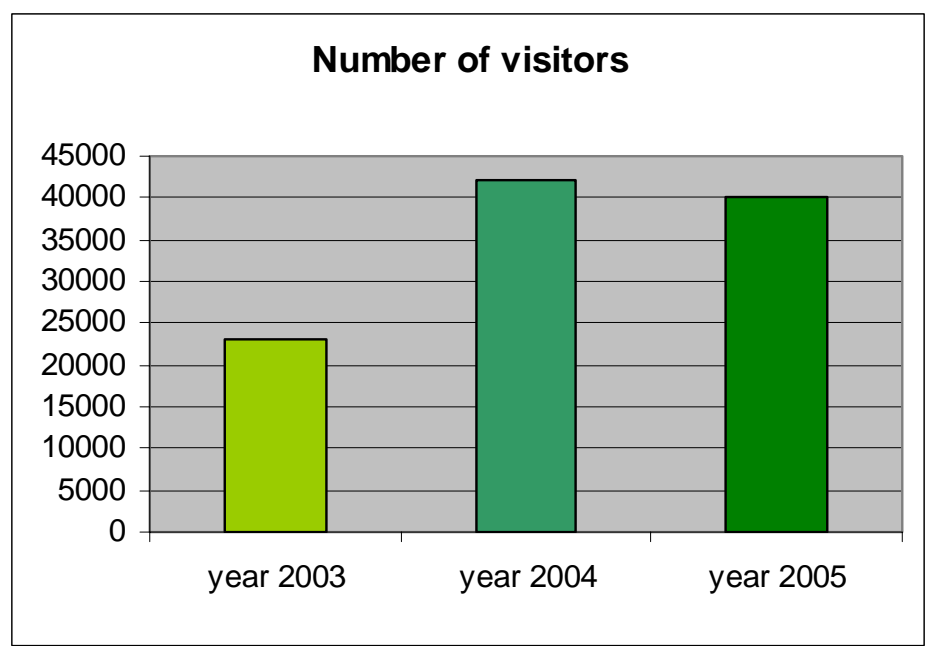

Figure 2. Growth of number of visitors to the Park

Several major restoration works in the salt making infrastructure were undertaken, which contributed to both production of salt and improved conditions for wildlife. More than 20 full time and more than 40 seasonal jobs have been created which is well appreciated by the local population.

Finally, the results of these efforts are reflected also in improved conditions for wildlife and restoration of cultural heritage: more than $22 \mathrm{~km}$ of dykes, 10 historical buildings, 18 salt pans etc. have been restored. The number of breeding birds has increased. This is demonstrated, for example, by the growth of number of breeding Little Terns (see Figure 3).

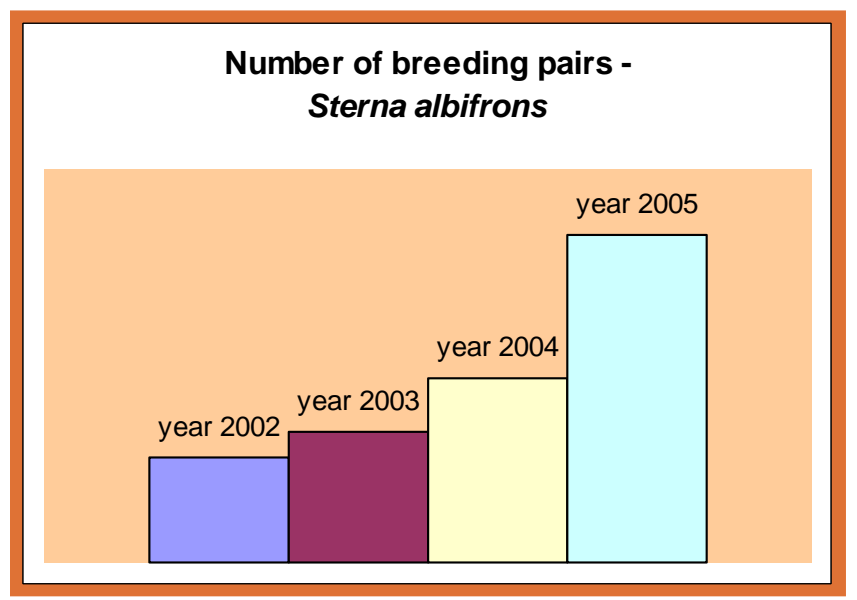

Figure 3. Growth of number of breeding Little Terns Sterna albifrons 


\section{CONCLUSION}

The model where business company decided to help in protection of natural and cultural heritage and salt making process was introduced in the area of Secovlje Salina Nature Park. Innovative model is based on the pre-condition that management of the protected area has to be followed by legal documentation (Decree on the Nature Park, Management Plan), issued by the Government of Slovenia who also directly oversee their implementation (through the Managerial Board with members appointed by the Government). The Government also approves yearly management plan. The initial support of the Mobitel d.d. has led to reconstruction of the salt making process and establishment of an effective management of the park (both for wildlife and for visitors). It is assumed that such kind of support will not be needed (or it will be greatly reduced) as these investments provide for the Park which can become self-sustainable in the next years.

\section{REFERENCES}

Rubinic B., (2000). Secoveljske soline. V: Polak, S. (ur.), Mednarodno pomembna obmocja za ptice v Sloveniji. DOPPS, Ljubljana. Pp.: 65-74

Žagar Z. (ed.), (1992). Muzej solinarstva. Museo delle saline. Katalog Pomorski muzej "Sergej Masera", No.7. Piran 